\title{
Markers of Endothelial Cells in Normal and Pathological Conditions
}

\author{
N. V. Goncharov ${ }^{a, b}$, P. I. Popova ${ }^{c}$, P. P. Avdonin ${ }^{d}$, I. V. Kudryavtseve, \\ M. K. Serebryakova ${ }^{e}$, E. A. Korf ${ }^{a}$, and P. V. Avdonin ${ }^{d, *}$ \\ ${ }^{a}$ Sechenov Institute of Evolutionary Physiology and Biochemistry, Russian Academy of Sciences, \\ St. Petersburg, 194223 Russia \\ ${ }^{b}$ Research Institute of Hygiene, Occupational Pathology and Human Ecology, \\ p.o. Kuz'molovskii, Leningrad oblast, 188663 Russia \\ ${ }^{c}$ City Polyclinic no. 19, St. Petersburg, 142238 Russia \\ ${ }^{d}$ Koltzov Institute of Developmental Biology, Russian Academy of Sciences, Moscow, 119334 Russia \\ ${ }^{e}$ Institute of Experimental Medicine, St. Petersburg, 197376 Russia \\ ${ }^{f}$ Far-East Federal University, Vladivostok, 690091 Russia \\ *e-mail: pvavdonin@yandex.ru \\ Received January 28, 2019; revised March 28, 2019; accepted April 2, 2019
}

\begin{abstract}
Endothelial cells (ECs) line the blood vessels and lymphatic vessels, as well as heart chambers, forming the border between the tissues, on the one hand, and blood or lymph, on the other. Such a strategic position of the endothelium determines its most important functional role in the regulation of vascular tone, hemostasis, and inflammatory processes. The damaged endothelium can be both a cause and a consequence of many diseases. The state of the endothelium is indicated by the phenotype of these cells, represented mainly by (trans)membrane markers (surface antigens). This review defines endothelial markers, provides a list of them, and considers the mechanisms of their expression and the role of the endothelium in certain pathological conditions.
\end{abstract}

Keywords: endothelium, markers, expression, cell aging, pathology

DOI: $10.1134 / \mathrm{S} 1990747819030140$

\section{INTRODUCTION}

Endothelial cells (ECs) form a kind of container for blood, the area of which in humans reaches $6000 \mathrm{~m}^{2}$ [1]. This is a unique diffuse tissue, the total weight of which is approximately $700 \mathrm{~g}$, and most of it (approximately $600 \mathrm{~g}$ ) forms the walls of capillaries [2]. Microvessels of the brain make up to $3-4 \%$ of its volume, their total length is close to $700 \mathrm{~km}$, and the surface of the exchange between blood and the parenchyma of the brain is about $20 \mathrm{~m}^{2}$ [3]. ECs originate from the mesoderm at the early stages of gastrulation.
Juvenile ECs form the primary vascular plexus and differentiate into arterial, venous, lymphatic, and capillary ECs (embryonic vasculogenesis). De novo formation of blood vessels occurs after birth due to endothelial progenitors (EPCs) of the bone marrow (postnatal vasculogenesis). However, angiogenesis, when new ECs are formed as a result of proliferation of existing ECs with varying degrees of specialization, is a more well-known mechanism for the formation of new blood vessels after birth. Differentiation and functional specialization of the ECs is one of the most important factors of specialization of a particular

Abbreviations: ACE, angiotensin-converting enzyme; ROS, reactive oxygen species; A $\beta$, amyloid- $\beta_{1-40}$; GGT, $\gamma$-glutamyltranspeptidase; BBB, blood-brain barrier; LDL, low-density lipoproteins; MAO, monoamine oxidase; CNS, central nervous system; ECs, endothelial cells; ER, endoplasmic reticulum; Ang, angiotensin; Angpt, angiopoietin; BMP-7, bone morphogenetic protein 7; CAM, cell adhesion molecules; Cav1, caveolin-1; ECFC, endothelial colony-forming cells; EGF, endothelial growth factor; EndoMT, endothelial-mesenchymal transition; EPC, endothelial progenitors; ESAM, endothelial selective adhesion molecule; ESDN, endothelial and smooth muscle cell-derived neuropilin-like protein; ET-1, endothelin 1; FAT, fatty acid translocase; FGF, fibroblast growth factor; GSK, glycogen synthase kinase; HIF, hypoxia inducible factor; HUVEC, human umbilical vein endothelial cells; ICAM-1, intercellular adhesion molecule-1; Ig, immunoglobulin; KTS, Klippel-Trénaunay syndrome; MCAM, melanoma cell adhesion molecule; MHC I, major histocompatibility complex class I; mTOR, mammalian target of rapamycin; NAADP, nicotinic acid adenine dinucleotide phosphate; ox-LDL, oxidized low-density lipoproteins; OP, osteogenic protein-1; PAMP, pathogen-associated molecular patterns; PECAM, platelet endothelial cell adhesion molecule; PI3K, phosphoinositide-3-kinase; PKC, protein kinase C; PRR, pattern recognition receptors; PTK, protein tyrosine kinase; RAS, renin-angiotensin system; TEM, tumor endothelial markers; TGF- $\beta$, transforming growth factor $\beta$; TM, thrombomodulin; TNAP, tissue non-specific alkaline phosphatase; TNF, tumor necrosis factor; VEGF, vascular endothelial growth factor; VWF, Willebrand factor; WPB, Weibel-Palade body; $\alpha-S M A$, smooth muscle $\alpha$-actin. 
organ as a whole. For example, five different types of ECs can be found in the heart: endocardial, coronary artery, venous, capillary, and lymphatic ECs; each of them has a corresponding phenotype [4]. Exchange of nutrients and regulatory molecules, as well as gas exchange occur in capillaries, where the ratio between the endothelial surface and blood volume is 100-500 times higher than in arteries and veins $[5,6]$. The actual vascular and tissue-specific functions of ECs are determined by the characteristics of parenchymal and smooth muscle cells, blood oxygenation, and the speed and intensity of blood flow. The most wellknown morphological phenotypes of the endothelium are continuous (blood-brain barrier), fenestrated (exocrine and endocrine glands, gastric and intestinal mucosa, vascular plexus, glomeruli and subpopulation of the renal tubules), sinusoidal, or intermittent (liver, spleen, bone marrow) [7]. ECs of the blood-brain barrier (BBB) form a continuous layer with dense contacts between cells and are devoid of fenestra, which significantly limits the para- and transcellular exchange of molecules [8]. In addition, ECs of BBB have a low expression of leukocyte adhesion molecules, which makes it almost impossible for immune cells to enter a healthy CNS [9]. Tissue non-specific alkaline phosphatase (TNAP) is among the characteristic markers of BBB, due to which ECs of brain capillaries differ from ECs of capillaries of other organs [3]. The expression of $\gamma$-glutamyltranspeptidase (GGT) and monoamine oxidase (MAO) is also characteristic of the ECs of brain microvessels $[10,11]$. On the contrary, thrombomodulin is practically absent in the brain ECs, while it is highly expressed in other ECs [5]. The transfer of macromolecules through the endothelium (transcytosis) in many tissues outside the BBB is mediated by caveolaes, vesicular-vacuolar organelles, and transendothelial channels. Caveolae density in the capillary endothelium can reach 10,000 per cell, which is significantly higher than in arteries, arterioles, veins, and venules [12]. The transport of low molecular mass substances occurs between the cells (paracellular pathway). Endocytosis of large molecules is most pronounced in the endothelium of the liver sinuses; this process involves areas of the membrane covered with clathrin from the cytoplasm side, whose polymerization leads to the formation of a vesicle [7]. Bone marrow ECs express E-selectin (CD62E) constitutively, whereas E-selectin is expressed only under inflammation in other types of ECs. The response to inflammatory cytokines and vasoactive agents varies significantly; as a rule, the reaction of postcapillary venules is more pronounced. Angiotensin-converting enzyme (ACE) is expressed in the ECs of small arteries and arterioles in all organs except the kidneys, while ECs of large arteries and veins weakly or do not express ACE [13].

A healthy endothelium is characterized by a vasodilating phenotype with a high content of nitric oxide (NO) and prostacyclin (PGI2), as well as a low content of uric acid and reactive oxygen species (ROS).
On the other hand, ECs are involved in the etiology of such common human diseases as stroke, diabetes and insulin resistance, heart disease, peripheral vascular disease, tumor growth and metastasis, chronic kidney failure, rheumatoid arthritis, and viral infections [14]. In the normal inactive state, ECs express MHC I (the major histocompatibility complex class I) and PRR (pattern recognition receptors) to detect PAMP (pathogen-associated molecular patterns). Inflammatory stimuli initiate the transition of ECs to a proinflammatory and procoagulant state. ECs express MHC II molecules in response to inflammatory stimuli that present endothelial antigens to immune cells [15]. An increase in the expression of other endothelial markers and cell adhesion molecules (CAM) after the impact of ROS or proinflammatory stimuli was also described [16, 17]. In large quantities, ROS exert negative effects on endothelial and other cells, while at low concentrations ROS have signaling functions and are continuously generated by cells. An imbalance in the generation and neutralization of ROS causes remodeling (transformation) of blood vessels. NADPH oxidases, mitochondria, xanthine oxidase, NO synthase, cytochrome P450, lipoxygenase, cyclooxygenase, peroxidase, MAO, and red blood cell hemoglobin are the sources of ROS in endothelial and/or neighboring cells [18-20].

Despite numerous studies, we are far from understanding the patterns of expression of endothelial markers both in normal and in various pathological conditions of the body.

\section{WHICH ENDOTHELIAL MARKERS CAN BE CONSIDERED AS MAJOR AND WHICH ARE SECONDARY?}

Protein molecules expressed on the cell surface often serve as markers of certain cell types, populations, or subpopulations. Morphological and ultrastructural features have also not lost their significance, although not so long ago they were the only signs by which it was possible to discern the type of cells; some cells still do not need special molecular markers for their identification (for example, red blood cells). As for ECs, von Willebrand factor (VWF), along with the Weibel-Palade bodies (WPB), ACE (CD143), and the cobblestone morphology specific to monolayer cultures, have long served as mandatory criteria for identifying and confirming the purity of the EC culture [21, 22]. A modern (though not exhaustive) list of endothelial markers with their characteristics is given in Table 1. However, endothelial markers that have become "classic" still remain a subject of numerous studies.

\section{MAIN MARKERS OF ENDOTHELIUM}

Weibel-Palade bodies (WPB) are endothelial-specific secretory organelles. They contain VWF, P-selectin 
Table 1. Markers of endothelial cells (modified from [23])

\begin{tabular}{|c|c|}
\hline Endothelial marker & Function \\
\hline$\overline{\mathrm{CD} 13 / \mathrm{APN}}$ & $\begin{array}{l}\text { CD13/aminopeptidase } \mathrm{N} \text { is a transmembrane peptidase that is induced in the vascular network } \\
\text { of solid tumors and is a powerful angiogenic regulator. CD13 functions as a modulator of signal } \\
\text { transmission and cell mobility by influencing the specific organization of the plasma mem- } \\
\text { brane, thereby regulating angiogenesis [24]. }\end{array}$ \\
\hline CD29/integrin $\beta 1$ & $\begin{array}{l}\text { Integrin } \beta 1 \text { participates in angiogenesis by controlling the branching of sprouting capillaries; it } \\
\text { inhibits the proliferation of ECs. In emerging vessels, integrin } \beta 1 \text { is necessary for proper local- } \\
\text { ization of VE-cadherin and integrity of intercellular contacts [25]. In addition, integrin } \beta 1 \text { is } \\
\text { necessary for interaction between cardiomyocytes and ECs [26]. }\end{array}$ \\
\hline CD31/PECAM-1 & $\begin{array}{l}\text { CD31, known as PECAM-1 (platelet endothelial cell adhesion molecule-1), is a glycosylated } \\
\text { transmembrane homophilic adhesion protein that is expressed in significant amounts in ECs } \\
\text { and is necessary for white blood cell migration, playing a key role in removing old neutrophils. } \\
\text { The extracellular domain of CD31 is released during apoptosis of ECs and can be found in the } \\
\text { serum of patients who have suffered a myocardial infarction, acute ischemic stroke, and multi- } \\
\text { ple sclerosis [27]. }\end{array}$ \\
\hline CD34 & $\begin{array}{l}\text { CD34 is a transmembrane phosphoglycoprotein first found in hematopoietic stem and progen- } \\
\text { itor cells. Cells that express CD34 are normally present in the umbilical cord and bone marrow: } \\
\text { these are hematopoietic cells, a subpopulation of mesenchymal stem cells, and endothelial pro- } \\
\text { genitors (EPCs). ECs of blood vessels and lymphatic vessels of the pleura can express CD34. } \\
\text { The presence of CD34 on non-hematopoietic cells is due to the common phenotype of progen- } \\
\text { itors and adult stem cells [28]. }\end{array}$ \\
\hline CD36/SR-B3 & $\begin{array}{l}\text { CD36 is known as a class 3B scavenger receptor (SR-B3), platelet membrane glycoprotein IV } \\
\text { (GPIV), glycoprotein IIIb (GPIIIb), thrombospondin receptor, collagen receptor, fatty acid } \\
\text { translocase (FAT), and as an innate immunity receptor. Upon ligand binding, CD36 triggers a } \\
\text { signaling cascade that mediates a wide range of pro-inflammatory responses. For example, } \\
\text { amyloid- } \beta_{1-40}(A \beta) \text {, interacting with CD36, activates the formation of superoxide anions by } \\
\text { NADPH oxidase [29]. }\end{array}$ \\
\hline CD39/ENTPD1 & $\begin{array}{l}\text { CD39 (ENTPD1) is an ectonucleotidase whose expression is pronounced on the surface of } \\
\text { ECs; it is also present on the surface of platelets and white blood cells. CD39 catalyzes extracel- } \\
\text { lular hydrolysis of ATP to ADP and AMP. CD39 molecules are released from the endothelium } \\
\text { of coronary vessels during ischemia-reperfusion, so that the level of circulating ectonucleoti- } \\
\text { dase reflects the degree of ischemic vascular damage [30]. The decrease or absence of the CD39 } \\
\text { activity is associated with vascular dysfunction and remodeling in pulmonary arterial hyperten- } \\
\text { sion [31], as well as with reduced liver regeneration [32]. }\end{array}$ \\
\hline CD44 & $\begin{array}{l}\text { Expression of CD44 in the colony-forming ECs (ECFCs) is associated with regulation of the } \\
\text { neurovascular trophic effect [33]. ECFCs are the mature EPCs ready for differentiation and } \\
\text { recovery of the EC population. They are located in the vascular bed and can migrate to places of } \\
\text { damage in the form of circulating ECs [34]. }\end{array}$ \\
\hline CD47 & $\begin{array}{l}\text { CD47 is an immunoglobulin functionally coupled with ICAM-1 (CD54), participating in intra- } \\
\text { cellular calcium mobilization, activation of Src and AKT1/PI3 kinase, increasing the permea- } \\
\text { bility of brain microvessels for transendothelial migration of T cells and diapedesis of other } \\
\text { blood cells [35]. }\end{array}$ \\
\hline CD54/ICAM-1 & $\begin{array}{l}\text { ICAM-1 (intercellular adhesion molecule-1) is a transmembrane protein whose expression } \\
\text { increases in endothelial and epithelial cells at sites of inflammation. ICAM-1 mediates adhesion } \\
\text { and paracellular migration of white blood cells expressing LFA-1 (CD11a/CD18) and Mac-1 } \\
\text { (CD11b/CD18). Soluble ICAM-1 is involved in angiogenesis and is an indicator of EC activa- } \\
\text { tion or damage. Increased levels of soluble (circulating in the blood) ICAM-1 are associated } \\
\text { with oxidative stress, hypertension, cardiovascular diseases, type } 2 \text { diabetes, graft dysfunction, } \\
\text { increased abdominal fat mass, liver diseases, certain malignancies, and sepsis [36]. }\end{array}$ \\
\hline
\end{tabular}


Table 1. (Contd.)

\begin{tabular}{|c|c|}
\hline Endothelial marker & Function \\
\hline CD61/integrin $\beta 3$ & $\begin{array}{l}\text { CD61 (integrin- } \beta 3 \text { ) is a protein involved in platelet aggregation. It was considered a marker only } \\
\text { for these cells; however, later it was detected on the surface of ECs, where it was coupled with } \\
\text { other proteins, in particular with disulfide isomerase [37]. }\end{array}$ \\
\hline CD62E/E-selectin & $\begin{array}{l}\text { E-selectin (endothelial leukocyte adhesion molecule-1, ELAM-1, CD62E) is one of three in } \\
\text { the selectin family (E-selectin, L-selectin, and P-selectin) that is transiently expressed in ECs in } \\
\text { response to IL-1 } \beta \text { and TNF- } \alpha \text {. }\end{array}$ \\
\hline $\begin{array}{l}\text { CD80/B7-1 } \\
\text { CD86/B7-2 }\end{array}$ & $\begin{array}{l}\text { Under certain conditions, ECs are antigen-presenting cells that express MHC molecules of class I } \\
\text { and II [15]. For example, in rat liver, hepatic sinus ECs express CD80 (B7-1) and CD86 (B7-2) } \\
\text { adhesion molecules in response to ischemia/reperfusion; CD80, CD86, and ICAM-1 expres- } \\
\text { sion is also increased in glomerular and peritubular ECs after ischemia/reperfusion [38]. }\end{array}$ \\
\hline CD93/C1qR1 & $\begin{array}{l}\text { C1qR1 (or C1qRp), collectin (a member of the family of soluble pattern recognition receptors, } \\
\text { PRR), AA4 antigen. It is a type I transmembrane glycoprotein found not only in ECs, but also } \\
\text { in hemopoietic progenitor cells, platelets, and cells of myeloid origin. C1qr1 molecules mediate } \\
\text { increased phagocytosis by monocytes and macrophages upon interaction with soluble protective } \\
\text { collagens, such as C1q, MBL, and SP-A. }\end{array}$ \\
\hline CD102/ICAM-2 & $\begin{array}{l}\text { ICAM-2 molecules are constitutively expressed in vascular ECs and lymphohemopoietic cells. } \\
\text { They are involved in T cell aggregation, cytotoxicity, and migration of NK cells. }\end{array}$ \\
\hline CD105/endoglin & $\begin{array}{l}\text { Endoglin is a transmembrane receptor of type III for ligands of the TGF- } \beta \text { superfamily that } \\
\text { plays an important role in smooth muscle cell differentiation, angiogenesis, and neovasculariza- } \\
\text { tion. Its expression is pronounced on proliferating ECs of vessels, chondrocytes and syncy- } \\
\text { tiotrophoblasts of the placenta. Elevated levels of antiangiogenic endoglin circulating in the } \\
\text { blood are a pathogenic marker in preeclampsia. }\end{array}$ \\
\hline CD106/VCAM-1 & $\begin{array}{l}\text { The vascular cell adhesion molecule } 1 \text { is involved in the adhesion of immune cells to vascular } \\
\text { ECs during inflammation. It interacts with integrins- } \alpha 4 / \beta 1 \text { (VLA- } 4), \alpha 4 / \beta 7, \alpha 9 / \beta 1 \text {, and } \\
\alpha \mathrm{D} / \beta 2 \text {. VCAM- } 1 \text { is constitutively expressed in the bone marrow, where it regulates the migra- } \\
\text { tion of T and B cells and hematopoietic progenitors. The soluble form of VCAM- } 1 \text { promotes } \\
\text { chemotaxis of monocytes. }\end{array}$ \\
\hline CD112/nectin-2 & $\begin{array}{l}\text { Nectins are type I transmembrane glycoproteins that are calcium-independent Ig-like adhesion } \\
\text { molecules. Nectin-1 (CD111, PRR1, mediator of herpes virus C entrance (HVEC), nectin-2 } \\
\text { (CD112, PRR2, and HVEB), and nectin-3 (PRR3) were detected in the adhesion contacts of } \\
\text { ECs, neurons, epithelial cells, and fibroblasts. }\end{array}$ \\
\hline CD117/c-Kit & $\begin{array}{l}\text { CD117/c-Kit is a receptor with tyrosine kinase activity that binds a stem cell factor; CD117/c- } \\
\text { Kit is a marker of certain types of hematopoietic progenitors in the bone marrow (hematopoietic } \\
\text { stem cells, multipotent progenitors, and common myeloid progenitors). Its expression is con- } \\
\text { sidered a distinctive feature of hemogenic ECs [39]. }\end{array}$ \\
\hline CD121a/IL-1 RI & $\begin{array}{l}\text { IL-1RI, also known as IL- } 1 \text { type } 1 \text { receptor and CD121a, is a transmembrane protein of the } \\
\text { Toll/IL-1R (TIR) superfamily. IL-1RI binds the pleiotropic cytokines IL-1 } \alpha \text { and IL-1 } 1 \beta \text {, as } \\
\text { well as an IL-1 receptor antagonist (IL-1Ra). IL-1RI is expressed mainly by T cells, fibroblasts, } \\
\text { and ECs, and its activation via NF-kB mediates the acute phase of inflammatory reactions. }\end{array}$ \\
\hline CD133/prominin-1 & $\begin{array}{l}\text { CD133, or prominin-1 is a glycoprotein, a representative of pentaspan transmembrane glyco- } \\
\text { proteins, which is localized in cellular protrusions. CD133 is expressed in hematopoietic stem } \\
\text { cells, EPC, glioblastoma cells, and many other cell types [40]. Although the exact function of } \\
\text { CD133 is unknown, it is assumed that it acts as an organizer of the cell membrane topology. In } \\
\text { ECFC cells, CD133 is expressed intracellularly and participates in vasculogenesis [41]. As an } \\
\text { example, in the blood of the patients with stroke, the level of stem cells (CD133+) and early } \\
\text { EPCs (CD133+CD309+) is increased, along with increased EGF and fibroblasts; inflamma- } \\
\text { tory processes cause a decrease in the level of angiogenic factors and EPCs [42]. }\end{array}$ \\
\hline
\end{tabular}


Table 1. (Contd.)

\begin{tabular}{|c|c|}
\hline Endothelial marker & Function \\
\hline $\begin{array}{l}\text { CD141/ thrombomodulin/ } \\
\text { BDCA-3 }\end{array}$ & $\begin{array}{l}\text { Thrombomodulin (TM, CD141, BDCA-3) is a transmembrane protein expressed in ECs, } \\
\text { smooth muscle cells of arteries, monocytes, and macrophages. It binds thrombin and enhances } \\
\text { thrombin-mediated activation of anticoagulant protein C and anti-fibrinolytic TAFI/carboxy- } \\
\text { peptidase B2. Thrombomodulin also inhibits the ability of thrombin to activate a number of } \\
\text { procoagulant proteins, such as fibrinogen, factors V and XIII, and PAR-1. The level of soluble } \\
\text { thrombomodulin fragments is increased in serum, urine, and synovial fluid in hemostatic disor- } \\
\text { ders and inflammatory processes. }\end{array}$ \\
\hline $\begin{array}{l}\text { CD142/blood clotting fac- } \\
\text { tor III/tissue factor/ } \\
\text { thromboplastin }\end{array}$ & $\begin{array}{l}\text { Tissue factor is an integral membrane protein expressed by many cell types, including ECs. It } \\
\text { serves as a cofactor/receptor for blood clotting factor VII. }\end{array}$ \\
\hline CD143/APF & $\begin{array}{l}\text { ACE and ACE2 are cell surface proteases that regulate blood pressure homeostasis and water- } \\
\text { salt balance mainly due to the formation of angiotensin II and inactivation of bradykinin. In } \\
\text { addition, ACE activity plays a role in immune status, reproduction, and regulation of neuropep- } \\
\text { tide activity. }\end{array}$ \\
\hline CD144/VE-cadherin & $\begin{array}{l}\text { Endothelial cadherin is a specific adhesion molecule located exclusively at the junctions } \\
\text { between ECs. EC adhesion involving VE-cadherin provides the control of vascular permeability } \\
\text { and extravasation of white blood cells. In addition, VE-cadherin participates in cell prolifera- } \\
\text { tion, apoptosis, and modulates EGF receptor functions [43]. }\end{array}$ \\
\hline CD146/MCAM & $\begin{array}{l}\text { CD146 is also known as the melanoma cell adhesion molecule (MCAM) and the cell surface } \\
\text { MUC18 glycoprotein. CD146 serves as a marker for ECs, including desquamated ones. MCAM } \\
\text { is a receptor for laminin- } \alpha 4 \text {, a molecule of the extracellular matrix of the vascular wall. MSAM } \\
\text { is also expressed by smooth muscle cells and pericytes. MCAM suppression accelerates the } \\
\text { aging of human cord blood mesenchymal stem cells [44]. In addition, MCAM is an unfavorable } \\
\text { prognostic factor for uterine sarcoma [45]. }\end{array}$ \\
\hline CD147/TRA-1-85 & $\begin{array}{l}\text { The TRA-1-85 antigen, or Oka blood group antigen, is considered a specific epitope of the bas- } \\
\text { igin protein known as EMMPRIN and CD147. This is a determinant of the cell surface, } \\
\text { expressed by almost all human cells. }\end{array}$ \\
\hline CD151 & $\begin{array}{l}\text { CD151 is a glycoprotein of the tetraspanin superfamily expressed by ECs, epithelial cells, mega- } \\
\text { karyocytes, and platelets. It interacts with other tetraspanins and integrins, such as } \alpha 3 / \beta 1 \text {, } \\
\alpha 6 / \beta 1, \alpha 6 / \beta 4 \text {, and } \alpha 7 / \beta 1 \text {. CD151 is involved in cell adhesion, migration, and activation of } \\
\text { platelets. }\end{array}$ \\
\hline CD160 & $\begin{array}{l}\text { CD160 is an anchored glycoprotein with a single Ig-like type V domain, found mainly in a sub- } \\
\text { population of cytolytic T cells and natural killers, where it serves as a receptor for class I MHC } \\
\text { and related molecules. CD160 expressed on ECs is involved in the transmission of antiangio- } \\
\text { genic signals and apoptotic cell death. }\end{array}$ \\
\hline CD201/EPCR & $\begin{array}{l}\text { EPCR (endothelial protein C receptor) is a transmembrane glycoprotein expressed on ECs. } \\
\text { EPCR inhibits thrombosis by interacting with protein C, activated protein C (aPC), and blood } \\
\text { VII and VIIa clotting factors. EPCR enhances the activation of protein C upon interaction with } \\
\text { thrombin-thrombomodulin complexes. The soluble form of EPCR suppresses the anticoagu- } \\
\text { lant activity of aPC. EPCR binds to CD11b/CD18 (Mac-1) on monocytes mediating the adhe- } \\
\text { sion of monocytes to the vascular endothelium. }\end{array}$ \\
\hline CD213a/IL-13R $\alpha 1$ & $\begin{array}{l}\text { Two members of the type I cytokine receptor subfamily } 5 \text { also serve as IL-13 receptors that bind } \\
\text { to IL-13R } \alpha 1 \text { (CD213a1, known as IL13Ra and NR4) with low affinity, and then interact with } \\
\text { the IL-4R } \alpha \text { chain to form a high affinity receptor capable of activating STAT6. In addition, IL-13 } \\
\text { can interact with IL-13ro2 (CD213a2) without activating STAT6, but producing TGF- } \beta \text {. }\end{array}$ \\
\hline
\end{tabular}


Table 1. (Contd.)

\begin{tabular}{l|l}
\hline \multicolumn{1}{c|}{ Endothelial marker } & \multicolumn{1}{c}{ Function } \\
\hline CD248/endosyalin & $\begin{array}{l}\text { Endosyalin, or endothelial tumor marker 1 (Tem1), is a 165 kDa transmembrane } O \text {-glyco- } \\
\text { sylated protein that contains one C-type lectin, one Sushi domain, one EGF-like domain, and a } \\
\text { mucin-like leg in the extracellular domain (ECD). It is expressed on activated perivascular and } \\
\text { stromal cells in embryonic and tumor vessels; its expression is suppressed in the mature vascular } \\
\text { network. Endosyalin regulates the proliferation, migration, and adhesion of pericytes to matrix } \\
\text { fibronectin and collagens I and IV. }\end{array}$
\end{tabular}

CD309/VEGFR2/KDR/Flk-1
VEGFR2 (EGF type 2 receptor) is a transmembrane receptor tyrosine kinase that mediates the angiogenic action of VEGF-A and VEGF-C. It is expressed mainly on vascular ECs and EPCs, and also in hematopoietic stem cells, endometrial epithelium, hepatic sinus cells, and many other cells. Increased CD309 expression leads to increased endothelial permeability in the microvascular bed [46].

ADAM 8, 9, 10, 12, 15, 17, Metalloproteases ADAM10 and ADAM17 with a disintegrin domain serve as the main regula33 tors of cytokines, growth factors, and adhesion molecules due to proteolytic shedding [46].

ADAM 12 and 17 expressed in ECs are responsible for breaking the hematoneural barrier under hypoxic conditions. This probably occurs as a result of proteolysis of Claudine-5, one of the molecules of dense EC contacts, since inhibition of ADAM metalloproteases in vivo restores impaired barrier function [47].

ADAMTS-13 $\quad$ ADAMTS-13 (disintegrin-like metalloprotease with repeat-13 thrombospondine type 1) is a zinc-containing metalloprotease that cleaves the VWF. ADAMTS-13 is synthesized in ECs and stellate liver cells, and is present in platelets. In addition, ADAMTS-13 is synthesized in kidney podocytes with subsequent deposition in the basal membrane of glomeruli, which prevents the formation of blood clots. ECs make a major contribution to the synthesis of ADAMTS-13 in the body [5].

\begin{tabular}{l|l}
\hline ADAMTS-18 & ADAMTS-18 is a member of a special family of proteases-disintegrins and metalloproteases
\end{tabular}
with thrombospondin motifs involved in angiogenesis and thrombosis. Violation of the regulation or mutation of these enzymes leads to inflammation, cancer, arthritis, atherosclerosis, and other diseases. Thrombin enhances the ADAMTS-18 secretion by ECs. Platelet aggregates can be destroyed by the C-terminal fragment of ADAMTS-18 [48].

\section{CXCL16}

Transmembrane CXC-chemokine ligand 16. Upon eryptosis, red blood cells attach to the ECs of the vascular wall, in particular, due to the interaction of phosphatidylserine exposed on the surface of red blood cells with endothelial CXCL16 [49].

DCBLD2/ESDN $\quad$ DCBLD2 (discoidin, CUB, and LCCL domain-containing protein 2), also known as ESDN (a neuropilin-like protein synthesized by ECs and smooth muscle cells) and CLCP1. DCBLD2 has structural similarities to neuropilins, VEGF receptors, and semaphorins; it is involved in cell movement and metastasis.

\begin{tabular}{l|l}
\hline Endomucin & $\begin{array}{l}\text { Endomucin (endothelial sialomucin; also endomucin-1/2 and mucin-14) is an 80-120 kDa } \\
\text { glycoprotein, a member of the endomucin family of proteins. It is expressed on ECs and func- } \\
\text { tions as a pro- or anti-adhesive molecule, depending on the nature of glycosylation. }\end{array}$ \\
\hline ESAM & $\begin{array}{l}\text { ESAM (endothelial selective adhesion molecule) is an EC-associated representative of a sub- } \\
\text { group of the CTX immunoglobulin superfamily. This molecule is associated with dense and } \\
\text { adhesive contacts, and modulates transendothelial cell migration, along with FGF-2. }\end{array}$ \\
\hline FABP & $\begin{array}{l}\text { Fatty acid binding proteins (FABP) are small cytoplasmic proteins that can bind free fatty acids, } \\
\text { cholesterol, and retinoids, thereby participating in their intracellular transport. Along with other } \\
\text { biomarkers, circulating FABP serve as indicators of tissue damage. In particular, hypoxia affects } \\
\text { FABP expression in ECs [50]. }\end{array}$ \\
\hline IgG (immunoglobulin G) & $\begin{array}{l}\text { Synthesis and secretion of FcRn and related IgG is activated under the influence of external } \\
\text { IgG in human umbilical vein endothelial cells (HUVEC) [50]. }\end{array}$ \\
\hline
\end{tabular}


Table 1. (Contd.)

\begin{tabular}{|c|c|}
\hline Endothelial marker & Function \\
\hline Integrin- $\alpha 4 \beta 1 /$ VLA-4 & $\begin{array}{l}\text { Integrin- } \alpha 4 \beta 1 \text { (VLA-4) and VCAM-1 provide intercellular adhesion between ECs and peri- } \\
\text { cytes. Integrin- } \alpha 4 \beta 1 \text { is expressed by proliferating ECs; VCAM- } 1 \text { is expressed by proliferating } \\
\text { mural cells. Antagonists of this interaction block the adhesion of mural cells to proliferating } \\
\text { ECs, thereby causing apoptosis of ECs and pericytes and inhibition of neovascularization [51]. }\end{array}$ \\
\hline KLF4 & $\begin{array}{l}\text { Kruppel-like factor } 4 \text { (KLF4) is a transcription factor and central regulator of angiogenesis via } \\
\text { the Notch signaling pathway [52]. Endothelial KLF4 is renoprotective; it provides statin- } \\
\text { induced protection against ischemic acute kidney injury (AKI) by regulating the expression of } \\
\text { cell adhesion molecules (CAM) and concomitant recruitment of inflammatory cells [53]. }\end{array}$ \\
\hline LYVE-1 & $\begin{array}{l}\text { Receptor-1 of the endothelial lymphatic vessel hyaluronan (LYVE-1) is a type I transmembrane } \\
\text { glycoprotein with molecular mass of } 60 \mathrm{kDa} \text {; it is a representative of the superfamily of binding } \\
\text { proteins. Hyaluronan is found in the extracellular matrix of most animal tissues and in biologi- } \\
\text { cal fluids. LYVE-1 modulates the behavior of cells during development, tissue remodeling, and } \\
\text { in various diseases; it is a marker of lymphatic ECs and is also expressed on the ECs of the liver } \\
\text { sinuses. LYVE-1 is also expressed, although to a lesser extent, in Kupffer cells, Langerhans } \\
\text { islands, cortical neurons, and renal epithelium. }\end{array}$ \\
\hline Notch & $\begin{array}{l}\text { Notch signaling is an evolutionarily conservative mechanism that is essential for the develop- } \\
\text { ment of the cardiovascular system. The contribution of Notch signaling to vascular homeostasis } \\
\text { is reflected in a new paradigm, according to which this pathway is sensitive to environmental } \\
\text { factors, inflammatory mediators, and nutritional components [54]. }\end{array}$ \\
\hline Podocalyxin & $\begin{array}{l}\text { Podocalyxin, also known as podocalyxin-like protein 1/PODXL or PCLP1, is a sialoglycopro- } \\
\text { tein, structurally related to CD34. It is expressed in embryonic stem cells and also serves as a } \\
\text { marker of hemangioblasts, common precursors of hematopoietic cells and ECs. }\end{array}$ \\
\hline Podoplanin & $\begin{array}{l}\text { Podoplanin, also known as T1 } \alpha \text { and Aggrus, is a transmembrane glycoprotein of the mucin type } \\
\text { with pronounced } O \text {-glycosylation. It is expressed by lymphatic ECs, as well as non-ECs in some } \\
\text { tissues. Podoplanin is involved in the regulation of lymphatic vessel formation and platelet } \\
\text { aggregation. }\end{array}$ \\
\hline RLIP76/RALBP1 & $\begin{array}{l}\text { RLIP76 (Ral-interacting protein of } 76 \mathrm{kDa} \text { ), also known as RalBP1 (Ral-binding protein 1), is } \\
\text { an ATP-dependent transporter of electrophile-glutathione conjugates [55]. }\end{array}$ \\
\hline Stabilin-1 and -2 & $\begin{array}{l}\text { Stabilin-1 and -2 are transmembrane representatives of the type I family of fascicline-like hyal- } \\
\text { uronan receptor homologues expressed on sinusoidal ECs and macrophages. Stabilin- } 1 \text { is } \\
\text { involved in getting rid of own unwanted molecules, whereas stabilin- } 2 \text { is a scavenger receptor for } \\
\text { hyaluronan and glycated proteins. }\end{array}$ \\
\hline TEM8/ANTXR1 & $\begin{array}{l}\text { Tumor endothelial marker } 8 \text { (TEM8) is one of eight members of the TEM family that are func- } \\
\text { tionally related to tumor angiogenesis. TEM } 8 \text { and CMG } 2 \text { (capillary morphogenesis gene 2) are } \\
\text { type I transmembrane proteins with the extracellular domain A of VWF. They are considered to } \\
\text { be representatives of the anthrax toxin receptor family. TEM8 is expressed at a high level in the } \\
\text { vascular network of solid tumors and can function as an adhesion molecule in capillary tubulo- } \\
\text { genesis. }\end{array}$ \\
\hline THSD1 & $\begin{array}{l}\text { THSD1 (protein } 1 \text { containing a type } 1 \text { thrombospondin domain), also known as a transmem- } \\
\text { brane molecule with a thrombospondin module (Tmtsp), is a type I transmembrane protein of } \\
95 \mathrm{kDa} \text {. It is strongly expressed in hematopoietic stem cells and progenitors. In addition, } \\
\text { THSD1 is widely represented in ECs, especially in the lungs. THSD1 is involved in the regula- } \\
\text { tion of vasculogenesis and/or angiogenesis. }\end{array}$ \\
\hline Tie- 1 and Tie-2 & $\begin{array}{l}\text { Tie-1/Tie and Tie-2/Tek are receptor tyrosine kinases with unique structural characteristics: } \\
\text { two immunoglobulin-like domains flanking three EGF-like domains, which are followed by } \\
\text { three fibronectin-like type III repeats in the extracellular region, and a splitted tyrosine kinase } \\
\text { domain in the cytoplasm. The Tie-2 receptor is an important regulator of endothelial barrier } \\
\text { function. The main ligands of Tie-2, angiopoietin } 1 \text { and } 2 \text {, exert an opposite effect on this } \\
\text { receptor in inflammatory conditions [56]. }\end{array}$ \\
\hline
\end{tabular}


Table 1. (Contd.)

\begin{tabular}{|c|c|}
\hline Endothelial marker & Function \\
\hline TNAP & $\begin{array}{l}\text { Tissue non-specific alkaline phosphatase (TNAP) is localized in the EC membranes of blood } \\
\text { vessels in the brain and in the membranes of neurons, where it induces neuronal toxicity by Tau } \\
\text { dephosphorylation. This function is involved in the loss of neurons, which is observed in Alzhei- } \\
\text { mer's disease. The level of TNAP is increased in the plasma of the blood in cerebrovascular dis- } \\
\text { eases and after brain injury }[3,57] \text {. }\end{array}$ \\
\hline TNF RII/TNFRSF1B & $\begin{array}{l}\text { TNFRII (tumor necrosis factor II receptor), also known as TNFRSF1B, p75/p80, and } \\
\text { CD120b, is one of the widely represented TNF- } \alpha \text { and lymphotoxin- } \alpha \text { receptors. Its activation } \\
\text { can initiate inflammation and EC survival via NF-kB-dependent signaling pathways; it can also } \\
\text { induce apoptosis. }\end{array}$ \\
\hline VE-statin & $\begin{array}{l}\text { VE-statin-secreted glycoprotein with molecular mass of } 41 \mathrm{kDa} \text {, a representative of a fairly large } \\
\text { family of proteins containing EGF-like domains. VE-statin is a marker of embryonic ECs, but is } \\
\text { also expressed in ECs of the adult body; its secretion blocks the migration of smooth muscle } \\
\text { cells. }\end{array}$ \\
\hline VG5Q & $\begin{array}{l}\text { Expression of the VG5Q, or AGGF1, protein is associated with Klippel-Trenaunay syndrome } \\
\text { (KTS), a congenital pathology of vascular morphogenesis. VG5Q is expressed in the ECs of ves- } \\
\text { sels of many tissues; its secretion contributes to the proliferation of neighboring ECs. }\end{array}$ \\
\hline VWF & $\begin{array}{l}\text { WWF is a glycoprotein involved in blood clotting; it mediates the attachment of platelets to dam- } \\
\text { aged ECs. VWF is released from WPB and has binding sites for factor VIII and heparin. The size } \\
\text { and function of VWF is regulated by the ADAMTS-13 protease. Violation of this function can } \\
\text { lead, in particular, to thrombotic thrombocytopenic purpura. VWF is also involved in the regu- } \\
\text { lation of angiogenesis [58]. }\end{array}$ \\
\hline
\end{tabular}

(CD62P), and angiopoietin-2 (Angpt2), which are involved in platelet binding, white blood cell recruitment, and inflammation modulation, respectively [59]. VWF is an important component of hemostasis; it binds platelets at sites of endothelial damage; it is produced in megakaryocytes and ECs [60]. VWF is found in approximately $80 \%$ of the cell population in the HUVEC culture [17]. VWF multimers are cut on the EC surface into shorter fragments by ADAMTS-13 metalloprotease, which binds to VWF-A3 domains and cuts individual VWF molecules at the Tyr1605Met1606 site inside the VWF-A2 domains [61]. This leads to the entry of smaller and more rounded multimers into the bloodstream, whose length in the extended state reaches $20 \mu \mathrm{m}$. Binding and splitting sites for ADAMTS-13 are hidden in their rounded structure, but become accessible at increased shear stress [62]. Endothelial VWF can participate in angiogenesis. Inhibition of VWF microRNA expression in ECs results in increased in vitro angiogenesis and increased VEGFR-2-dependent proliferation and migration, combined with reduced integrin- $\alpha v \beta 3$ levels and increased angiopoietin-2 release; in addition, increased vascularization was observed in mice with VWF deficiency [58]. The loss of VWF in ECs leads to increased and dysfunctional angiogenesis, which is consistent with clinical observations that vascular malformations can cause severe gastrointestinal bleeding in some patients with von Willebrand disease [63].
ACE (CE 3.4.15.1), one of the main components of the renin-angiotensin system (RAS), is a C-terminal dipeptidyl carboxypeptidase I that converts angiotensin I to vasoconstrictor angiotensin II and cleaves bradykinin [64], as well as a beta-amyloid protein [65]. In humans, ACE is expressed in about $20 \%$ of capillary ECs in each organ, with the exception of lungs and kidneys. Specifically, all capillary ECs in human lungs express ACE, whereas in the renal vascular network ACE is absent. Homogeneous endothelial expression of ACE in rats, unlike humans, is observed in the arteries and veins of all organs; however, low expression of ACE was detected in the kidney vessels. A reduced expression of ACE in the renal vascular network can protect the renal circulation from excessive angiotensin II formation and kinin depletion, which allows maintaining renal blood flow [13]. ACE2 is a relatively new component of RAS. It is known since 2003, when it was found that ACE2 is a receptor for SARS coronavirus, and that normal levels of ACE2 in the lungs are necessary to fight inflammatory lung diseases [66]. Thus, the active peptides of RAS are angiotensin II (Ang II), Ang III, Ang IV, and Ang (1-7), among which Ang II and Ang (1-7) appear to be the most important in terms of maintaining normal physiological functions and in pathogenesis [67]. The functional effects of Ang (1-7), that is, vasodilation, natriuresis, inhibition of proliferation, and increased activity of the bradykinin-NO (nitric oxide) system, are very different from those of stimulation of the 
AT(1) receptor. The catalytic efficiency of ACE2 is approximately 400 times higher with Ang II as a substrate than with Ang I [68]. The product of Ang (1-7) proteolysis acts on a special receptor, the Mas oncogene [69], so that the ACE2/Ang(1-7)/Mas axis can be considered as a counterweight system to the ACE/AngII/AT(1) axis. This signaling pathway includes Akt phosphorylation, RAS activation, and MAP kinase inhibition. Cofilin-1, an intracellular actinmodulating protein, binds and depolymerizes filamentous F-actin and inhibits the polymerization of monomeric G-actin; it also participates in the movement of the actin-cofilin complex from the cytoplasm to the nucleus, playing a dominant role in the Ang(1-7)induced inhibition of the cell cycle at the G0/G1 stage and autophagy of the human aortic ECs [70].

VEGF1-3 receptors contain an extracellular segment with seven immunoglobulin-like domains, a transmembrane segment, a juxtamembrane segment, a protein kinase domain with an insertion of about 70 amino acid residues, and a C-terminal tail. VEGF-A stimulates activation of preformed VEGFR2 dimers by autophosphorylation of tyrosine residues in the activation segment followed by phosphorylation of tyrosine residues of other proteins, which leads to recruitment of phosphotyrosine-binding proteins and signaling via ERK1/2, AKT, Src, and p38 MAP kinase pathways [71]. The formation of blood vessels is mainly due to angiogenesis, that is, the sprouting of ECs from existing vessels. The vascular network expands when sprouts form new connections, and vascular anastomoses are spatially regulated by VEGFR1 (Flt1), which acts as a trap receptor [72]. VEGFR1 modulates the activity of VEGFR2, the main regulator of vasculogenesis and angiogenesis. Oxidized lowdensity lipoproteins (ox-LDL) disrupt angiogenesis by degradation of VEGFR2, inhibit the formation of umbilical vein EC rings, and induce at the same time their apoptosis [73]. VEGFR3 and its ligands (VEGF$\mathrm{C}$ and VEGF-D) are mainly involved in lymphangiogenesis [71].

In addition to the signal pathway from the VEGF receptor, there is another specific signal pathway in ECs through the angiopoietin (Angpt)-Tie system, which is necessary for the embryonic development of the cardiovascular and lymphatic systems. The AngptTie system also controls postnatal angiogenesis, remodeling, and vascular permeability. This system is involved in the pathogenesis of many diseases, such as cancer, sepsis, diabetes, atherosclerosis, etc. Mutations in the Tie-2 signaling system disrupt vascular morphogenesis, causing venous malformations and primary congenital glaucoma [74]. The expression in ECs of Tie-2, its Tie-1 paralog, VE-PTP (tyrosine phosphatase), and the Angpt-2 ligand is well pronounced [56]; while Angpt-1 is secreted by pericytes [75]. In a healthy vascular network, Tie- 2 is phosphorylated in the intracellular domain by tyrosine residues; this contributes to increased barrier and anti-inflam- matory function. During inflammation, Angpt-2 is rapidly released from WPB and simultaneously activated for transcription; Angpt-2 is an Angpt-1 antagonist; it suppresses signaling via Tie-2 [56]. Hypoxia increases Angpt-1 expression due to HIF $2 \alpha$-mediated transcription activation in pericytes [76]. At the same time, under conditions of hypoxia, the activity of VE-PTP increases in ECs, which causes the suppression of Tie-2 activation by endothelial Angpt-2; this process is significantly pronounced in retinal neovascularization [78]. Tie-2 activated by Angpt-1 stimulates Rap1 GTPase, which reduces radial (stress) fibers by Rac1 and non-muscular myosin II, independently of VE-cadherin. On the other hand, the Angpt1-Tie2 link also recruits VE-PTP into interendothelial contacts, where VE-PTP dephosphorylates Tie-2 and increases vascular permeability [74]. In addition, activation of the VEGFR2-dependent signaling pathway causes phosphorylation of VE-cadherin followed by beta-arrestin-dependent endocytosis of VE-cadherin and rupture of interendothelial contacts [77]. In this case, VE-PTP dephosphorylates VEGFR2 at interendothelial contacts via a Tie2-dependent mechanism. This suppresses phosphorylation of tyrosine in VE-cadherin and contributes to the strengthening of functional integration of ECs and the formation of a lumen in the capillaries [74]. Thus, endothelial permeability is controlled through complex interactions of angiopoetins, VEGF, their receptors, VE-cadherin, and VE-PTP. Targeted therapy aimed at VE-PTP and other components of this molecular complex can stabilize blood vessels, at least in patients with retinal and vascular diseases [78].

Cell adhesion molecules (CAM) constitute a significant group of endothelial markers (at least twenty) that participate in homo- or heterophilic binding to other cells or the extracellular matrix. All representatives of the main four CAM families (immunoglobulins, integrins, cadherins, and selectins), including $\mathrm{IgG}$, are expressed on the EC surface [50]. Platelet endothelial cell adhesion molecule (PECAM-1, $\mathrm{CD} 31$ ) is a $130 \mathrm{kDa}$ protein that is widely present in endothelial and hematopoietic cells. It maintains the integrity of blood vessels and participates, despite the name, mainly in the interaction of white blood cells with the endothelium and their transendothelial migration during inflammation [79]. Damage to ECs of the $\mathrm{BBB}$ is one of the pathogenetic or concomitant factors of Alzheimer's and Parkinson's diseases, multiple sclerosis, some cases of bacterial meningitis, trauma, and ischemia associated with the presence of a tumor. PECAM- 1 and its soluble form (sPECAM-1) are potential markers of these and other diseases and possible targets for therapy.

Inflammation modulates gene expression by the activation of NF-kB and other transcription factors. Inflammatory mediators can affect BBB permeability via RLIP76 (also known as RALBP1), an ATP-dependent transporter of electrophile-glutathione conju- 
gates [56]. Adhesive contacts are the main component of intercellular adhesion; they consist of transmembrane cadherins that form homotypic interactions between neighboring cells and interact with cytoplasmic catenins, which in turn interact with the cytoskeleton. When inflammation occurs, the adhesive contacts are separated, and small molecules diffuse through the resulting slits, and white blood cell migration occurs. White blood cell adhesion to ICAM-1 (CD54), VCAM-1 (CD106) and CD47 induces activation of small GTPases (Rac1, RhoA, RhoG) and signaling via PTK, coupled with activation of Src and Pyk2 [6]. ICAM-1 is one of the main adhesion molecules that causes changes in vascular permeability and transendothelial migration of white blood cells. ICAM-1 expression increases after activation of ECs by proinflammatory stimuli, whose action is mediated by signaling pathways involving Akt/PKB, NF-kB, p38 and ERK1/2 MAP-kinases [80]. ICAM-1 expression in the cerebral vascular ECs increases four hours after the stimulus and remains elevated up to $72 \mathrm{~h}$ even after a short-term exposure [81]. The ICAM-1 protein binds to CD11/CD18 and LFA-1 integrins of white blood cells, mainly neutrophils, after which they easily penetrate into tissues [82]. It is important to note that this interaction leads to increased generation of $\mathrm{H}_{2} \mathrm{O}_{2}$ by neutrophils, that is, it is a necessary condition for forming a positive feedback. In vivo, ICAM-1 is removed from the EC surface (shedding), which then acts as an independent signaling agent that supports the inflammatory process in the endothelium [83]. Moreover, ICAM-1 recirculation occurs after interaction with ligands with its internalization, signal transfer to lysosomes, and reintegration into the plasma membrane [84]. This process is controlled by PKC and the $\mathrm{Na}^{+} / \mathrm{H}^{+}$exchanger, which contribute to the retention and/or integration of ICAM-1 in the plasma membrane of ECs [85]. Thus, studies of endothelial phenotype regulation are quite interesting, important and have great perspectives.

\section{MODULATORS OF THE STATE AND AGING OF ENDOTHELIAL CELLS. ENDOTHELIAL- MESENCHYMAL TRANSITION}

The impact of many factors determines the phenotype and lifespan of ECs. They respond within minutes to changes in hemodynamics, as well as to vasoactive, thrombogenic or inflammatory agents. Rapid responses follow receptor-mediated linear signaling pathways associated with the entry and/or mobilization of calcium ions, activation of phosphorylation and various enzymes. In many cases, the imbalance of calcium is preceded by ROS-induced EC dysfunction. The endoplasmic reticulum (ER), mitochondria, Golgi apparatus, and lysosomes are calcium ion reservoirs. About $75 \%$ of $\mathrm{Ca}^{2+}$ ions of ECs are in the ER and up to $25 \%$, in mitochondria [86]. The mitochondria of EC are a branched network that is in close con- tact with the calcium channels of ER and the plasma membrane [87]. There were identified 11 molecular sources of mitochondrial ROS [18]. Reperfusion/reoxygenation induces calcium fluctuations [88], which affect the state of mitochondria and enhance the generation of ROS [89], as well as the expression and exocytosis of adhesion molecules [90]. This aggravates the pathological state of the endothelium due to infiltration of white blood cells that produce their own ROS. In turn, ROS activate the IP3- and ryanodine calcium channels of the ER and some channels of the TRP superfamily of the plasma membrane, leading to calcium overload of ECs [91]. TRPM2 in ECs are considered to be the main channels for the entry of $\mathrm{Ca}^{2+}$ ions [92]. TRPM2 are nonselective cation channels with endogenous ligands ADP-ribose (ADPr) and nicotinic acid adenine dinucleotide phosphate (NAADP); $\mathrm{Ca}^{2+}$ ions and $\mathrm{H}_{2} \mathrm{O}_{2}$ molecules can potentiate TRPM2 activation [93]. TRPM2 channels are considered to be sensors of oxidative stress and redox status of cells; their activation causes endothelial dysfunction and increases the probability of cell death [94]. As an example, extracellular accumulation of $A \beta$ in Alzheimer's disease impairs endothelial structure and function by activating TRPM2; this leads to the $\mathrm{Ca}^{2+}$ overload of the cells and vasomotor dysfunction [95]. Exogenous hydrogen peroxide increases $\left[\mathrm{Ca}^{2+}\right]_{i}$ and reduces transmembrane electrical resistance in ECs of lung microvessels by activating TRPV4 [96]. In addition, $\mathrm{H}_{2} \mathrm{O}_{2}$ at low non-toxic concentrations causes an increase in $\left[\mathrm{Ca}^{2+}\right]_{\mathrm{i}}$ in cultured umbilical vein ECs due to the release of calcium through the two-pore channels of endolysosomal vesicles [97].

The mechanisms of development of endothelial barrier dysfunction may vary depending on the activating agent and the predominant or primary type of ROS. Since $\mathrm{H}_{2} \mathrm{O}_{2}$ is the most stable type of ROS, it is used in most experiments to modify the redox state of cells and study the signaling and toxic effects of ROS. The cytotoxic effect of $\mathrm{H}_{2} \mathrm{O}_{2}$ on ECs is associated with depletion of intracellular glutathione, activation of redox-sensitive p38 MAPK and JNK kinases, transmission of Akt signals involving NF-kB, increased expression of aldose reductase, decreased Sirt6 levels, and increased expression and activity of $\beta$-galactosidase $[98,99]$.

Most mammalian cells can respond to stressors with a special change in the phenotype associated with senescence rather than death. This phenotype in ECs is proinflammatory, proatherosclerotic, and prothrombotic [100]. There are two types of cellular senescence: replicative senescence with telomere depletion and stress-induced premature senescence without telomere involvement. Both types of cellular senescence lead to a stop in the growth of ECs and a violation of their functions, thereby contributing to the development of cardiovascular diseases [101]. As an 
example, activation of the renin-angiotensin-aldosterone and endothelin systems causes endothelial dysfunction, vascular remodeling, and endothelial senescence, which causes the production of ROS and stimulation of inflammation and cell growth [102]. Changes in the metabolism of nitric oxide and prostanoids, endothelin-1, thrombomodulin, and VWF affect the procoagulant status that emphasizes the role of endothelium in the development of thrombosis [103]. Sirtuins SIRT1, SIRT3 and SIRT6 prevent aging of ECs and blood vessels [101]. In parallel with senescence and under chronic oxidative stress, inflammation, and the influence of insulin-like growth factor 2 and transforming growth factor- $\beta$ (TGF- $\beta$ ), ECs can contribute to the development of fibrosis through the endothelial-to-mesenchymal transition (EndoMT) [104]. This is a process in which certain subpopulations of ECs lose their endothelial characteristics and transform into smooth muscle or mesenchymal-like cells that are subject to further redifferentiation into mesodermal cells, including osteoblasts, chondrocytes, and adipocytes [105]. The initiation of reprogramming is carried out with the participation of EndoMT-specific transcription factors Slug, Snail, Twist and Zeb1/2. This event is associated with loss of apical-basal polarity and rupture of intercellular contacts. It is important to note that these changes persist even after the removal of inducing agents and are associated with functional changes: a decrease in the capture of acetylated LDL, migration ability, and the ability to synthesize collagen de novo [106]. It is still unclear which regulatory signals determine full or partial EndoMT. A certain role in this process is played by the contactdependent Notch signaling pathway [107]. EndoMT promotes fibrosis of the heart, lungs, liver, cornea, and other organs.

Binding of TGF- $\beta$ with subsequent activation of Smad-dependent and Smad-independent signaling is considered the most important way to initiate EndoMT [108]. Increased NOX4 expression caused by TGF- $\beta$ results in Snaill-mediated EndoMT. In addition, ET-1 synergistically enhances TGF- $\beta$ induced EndoMT with the participation of canonical Smad pathways. Hypoxia is another factor that induces EndoMT through HIF1alpha-mediated activation of Snaill, the most important EndoMT regulator. The level of Snail1 is regulated by GSK3-mediated phosphorylation of Snail1, which undergoes proteasomal degradation. Caveolin Cav1, in contrast, suppresses EndoMT through internalization of TGF- $\beta$ receptors with their subsequent degradation. EndoMT is also modulated by morphogens Wnt, Sonic $\mathrm{Hh}$, Notch, and others. If these intracellular signaling events activate genes specific to mesenchymal cells, this leads to increased synthesis of myofibroblast-specific and profibrotic macromolecules, including $\alpha$-SMA, COL1, COL3, FN, COMP, and TIM (an MMP inhibitor). Simultaneously, EC-specific markers such as CD31/PECAM-1, VE-cadherin, and VWF are suppressed, which leads to the phenotypic transformation of ECs into myofibroblasts responsible for the fibrous process [108].

It was shown that the level of miRNA-20a (miR-20a) decreases with EndoMT, and the restoration of its expression under the action of fibroblast growth factor-2 (FGF) correlates with EndoMT regression [109]. In contrast, miR-21 levels increase after exposure to TGF- $\beta$, which leads to increased EndoMT, while blocking the expression of endothelial miR-21 suppresses EndoMT [110]. Thus, these two microRNAs act above (miR-20a) and below (miR-21) activated TGF- $\beta$ signaling, respectively [111]. TGF- $\beta$ is considered to be the main mediator of EndoMT, while bone morphogenetic protein 7 (BMP-7), also referred to as osteogenic protein-1 (OP-1), and FGF can both enhance and weaken TGF-controlled EndoMT depending on conditions [112]. In addition, endothelial autophagy also reduces the level of EndoMT. Rapamycin and trehalose, autophagy inducers, counteracted EndoMT by suppressing Smad3 phosphorylation and reducing Snail expression [113]. The results published in 2014 have shown the ability of heart fibroblasts to accept the endothelial phenotype after acute ischemic injury [114]. ECs formed from fibroblasts had morphofunctional characteristics of native ECs; moreover, p53 induction in heart fibroblasts enhances the mesenchymal-endothelial transition, improves blood circulation and the functional condition of the heart.

Clinicians prescribe cyclophosphamide to suppress EndoMT in interstitial lung disease associated with systemic sclerosis, while mycophenolate or methotrexate is used under less dangerous skin lesions. Among the new drugs that modulate fibrosis and inflammation in systemic sclerosis, we note tocilizumab, pirfenidone, tyrosine kinase inhibitors, lysophosphatidic acid, and NOX4 inhibitors [115]. Natural compounds geniposide (iridoid glycoside isolated from Gardenia fruit) and glycyrrhizin (saponin from licorice root) seems to be promising. Geniposide eliminates bleomycin-induced capillary loss and fibrosis, weakens the expression of key EndoMT factors (Slug, Snail, and Twist), and suppresses mTOR and S6 kinases [116]. Glycyrrhizin also reduces cutaneous fibrosis caused by bleomycin, which is associated with blocking the TGF- $\beta$ signaling in dermal fibroblasts by suppressing thrombospondin 1 , the latent TGF- $\beta$ receptor, and transcription factors Smad3 and Ets1. Bleomycin-dependent immune response disorders and EndoMT were significantly less pronounced in mice with administered glycyrrhizin [117].

\section{THE DYNAMICS OF MARKER EXPRESSION IS THE BASIS OF THE CONCEPT OF CYTOTOXIC POWER}

The effectiveness of work in the field of experimental and clinical medicine largely depends on our ideas 
about the reaction of cells to various stimuli and requires the development of new theoretical and applied tools. The concept of "cytotoxic power" may be one of these tools, the original version of which was published earlier [118]. Currently accepted concepts of "apoptotic index" and "apoptotic potential" are insufficient for adequate quantitative assessment and analysis of pro-apoptotic activity of chemicals within a wide range of therapeutic and toxic doses; therefore the concept of "cytotoxic power" was developed as an alternative to these indicators; the essence of it is that the final calculations of efficiency values are carried out in in vitro experiments not only after taking into account the temporary development of the process of cell death, but also after taking into account the ratio of the amount of substance to the number of cells studied. The cytotoxic power $(P)$ of a substance can be mathematically represented as the ratio of the product of the amount of substance $(S)$ expressed in moles to the intensity of the cytotoxic process $(I$, a special case of the signal intensity indicating the expression of a particular marker of ECs or other cells) to the square of the number of cells per unit of time $(t)$ :

$$
P=\frac{I S}{n^{2} t}
$$

The concept and the corresponding calculation algorithm of the cytotoxic power make it possible to perform the correct transformation of the quantized dependence into a graded one by a multi-factor search strategy, and, along with relatively universal and nonspecific cytotoxicity indicators, to identify and use tissue-specific indicators (markers), the components of the so-called phenome. For cell death of any type, it is possible to identify markers whose level (number) gradually increases or decreases before cell death. The level of expression of each marker depends on the dose (amount) of the cytotoxic substance. It is important to note that the expression is observed in living cells regardless of what percentage of dead cells is recorded. Moreover, along with this, it is possible to determine the expression of markers by cells at the stage of early apoptosis or autophagy, since these cells are considered to be still alive. Thus, the intensity of the development of a particular signal reflects an increase in the number of discrete, functionally coupled, relatively stable and, at the same time, transient intracellular structures that are components of the cell phenome; we call them "phens" $(F)$. In this case, the intensity or power of the cytotoxic process can be expressed by the formula $I=F / t$. The unit of measurement of the cytotoxic power of a substance is a "molphen", the number of nanomoles of a substance that changes the intensity of expression of phenotypic markers (components of the phenome) by 100 arbitrary units per an hour from the beginning of exposure per 1000 cells. This definition, which is not claimed to be final and complete, attaches particular importance to the quantitative ratio of phens and the number of cells, as well as to different initial states of cells, which explains the differences in the dynamics of cell death within the population. The concept of cytotoxic power can facilitate the integration of data obtained in vitro on different cell types with the results of in vivo studies.

\section{CONCLUSIONS}

Endothelium occupies a strategic position between the blood and interstitial tissues, so that ECs integrate the functions of barrier tissue, a source of numerous mediators and a participant in many physiological processes. Because of this, ECs are the object of a various types of therapy. Vascular pathology is usually caused by various factors, including genetic and environmental factors, so that the response of cells to a wide range of effects is also multidimensional; however, modern treatment methods are aimed mainly at individual signaling molecules involved in pathophysiological pathways. This approach to study the phenotype is governed by the "one gene/one trait" hypothesis by default. Meanwhile, omic technologies make it possible to describe the origin (etiology) and essence (pathophysiology) of EC-dependent pathologies in the form of a set of "big data" as a new information technology phenomenon; it also makes it possible to identify new relationships between the set and variability of data and the inherently limited traditional definition of clinical phenotypes of vascular diseases [119].

Phenomics, a strategy that was announced about two decades ago [120], gradually changed the traditional phenotype/genotype/genome approach to a new paradigm of biological research-the phenome/genome/proteome triad. A phenotype is a set of all the phenotypic features of an organism that are determined by the expression of the genome and the specific impact of the environment in dynamics. Phenomics is a new approach to quantify the correlation between multiple phenotypic traits and the variability of the transcriptome, proteome, metabolome, interactome, and environmental factors, along with the genome. The development of phenomics will not only identify a set of biomarkers for the diagnosis of vascular pathology, but also reveal new targets for combined therapy, as well as new testing systems for evaluating the chemical safety and/or therapeutic effectiveness of substances (effects in the broad sense), thereby making a revolutionary shift in the paradigm of preclinical drug testing [119].

Currently, an increased attention is attracted by indicators of the general quality of diet, in difference from individual components of the food or its calorie content. This is especially true for assessing the state of the endothelium and treatment of vascular diseases. There is a close relation between nutritional structure and expression of the endothelial markers. Conditionally healthy foods or meals, in particular fruits and vegetables, consumed regularly, have a positive effect on the functional state of endothelium, which can be 
assessed by the level of its markers, such as SICAM-1, sVCAM-1, E-selectin, and several others. "Western" diet (mainly meat, sweets, refined and fried foods) correlates with the expression of inflammation and atherogenesis markers [121]. Besides, moderate physical activity positively influences both endothelial markers and cognitive abilities in the elderly [122].

New concepts, research methods, data processing, and targeted effects on cells and the body as a whole give confidence in the development of more natural approaches to solve vascular health problems and human diseases.

\section{ACKNOWLEDGMENTS}

The work was supported by the Russian Science Foundation (project no. 18-15-00417).

\section{COMPLIANCE WITH ETHICAL STANDARDS}

The authors declare that they have no conflict of interest.

This article does not contain any studies involving animals or human volunteers by any of the authors.

\section{REFERENCES}

1. Gimbrone M. 1986. Vascular endothelium: Nature's blood container. In: Vascular endothelium in hemostasis and thrombosis. New York: Churchill Livingstone, pp. 1-13.

2. Wolinsky H. 1980. A proposal linking clearance of circulating lipoproteins to tissue metabolic activity as a basis for understanding atherogenesis. Circ. Res. 47 (3), 301-311.

3. Deracinois B., Lenfant A.M., Dehouck M.P., Flahaut C. 2015. Tissue non-specific alkaline phosphatase (TNAP) in vessels of the brain. Subcell. Biochem. 76, 125-151.

4. Ishii Y., Langberg J., Rosborough K., Mikawa T. 2009. Endothelial cell lineages of the heart. Cell Tissue Res. 335 (1), 67-73.

5. van Hinsbergh V.W.M. 2012. Endothelium-role in regulation of coagulation and inflammation. Semin. Immunopathol. 34 (1), 93-106.

6. Adam A.P. 2015. Regulation of endothelial adherens junctions by tyrosine phosphorylation. Mediators Inflamm. 2015, Article ID 272858, 24.

7. Aird W.C. 2012. Endothelial cell heterogeneity. Cold Spring Harb. Perspect. Med. 2 (1), article a006429.

8. Abbott N.J., Ronnback L., Hansson E. 2006. Astrocyte-endothelial interactions at the blood-brain barrier. Nat. Rev Neurosci. 7 (1), 41-53.

9. Ransohoff R.M., Engelhardt B. 2012. The anatomical and cellular basis of immune surveillance in the central nervous system. Nat. Rev. Immunol. 12 (9), 623-635.

10. Meresse S., Dehouck M.P., Delorme P., Bensaïd M., Tauber J.P., Delbart C., Fruchart J.C., Cecchelli R. 1989. Bovine brain endothelial cells express tight junctions and monoamine oxidase activity in long-term culture. J. Neurochem. 53 (5), 1363-1371.
11. Yu C., Kastin A.J., Ding Y., Pan W. 2007. Gamma glutamyl transpeptidase is a dynamic indicator of endothelial response to stroke. Exp. Neurol. 203 (1), 116-122.

12. Bendayan M. 2002. Morphological and cytochemical aspects of capillary permeability. Microsc. Res. Tech. 57 (5), 327-349.

13. Metzger R., Franke F.E., Bohle R.M., Alhenc-Gelas F., Danilov S.M. 2011. Heterogeneous distribution of angiotensin I-converting enzyme (CD143) in the human and rat vascular systems: Vessel, organ and species specificity. Microvasc. Res. 81 (2), 206-215.

14. Rajendran P., Rengarajan T., Thangavel J., Nishigaki Y., Sakthisekaran D., Sethi G., Nishigaki I. 2013. The vascular endothelium and human diseases. Int. J. Biol. Sci. 9 (10), 1057-1069.

15. Mai J., Virtue A., Shen J., Wang H., Yang X.F. 2013. An evolving new paradigm: Endothelial cells - conditional innate immune cells. J. Hematol. Oncol. 6 (1), 61.

16. Mutin M., Dignat-George F., Sampol J. 1997. Immunologic phenotype of cultured endothelial cells: Quantitative analysis of cell surface molecules. Tissue Antigens. 50 (5), 449-458.

17. Kudryavtsev I.V., Garnyuk V.V., Nadeev A.D., Goncharov N.V. 2014. Hydrogen peroxide modulates expression of surface antigens by human umbilical vein endothelial cells in vitro. Biochem. (Moscow) Suppl. Ser. A: Membr. Cell Biol. 8 (1), 97-102.

18. Mailloux R.J. 2015. Teaching the fundamentals of electron transfer reactions in mitochondria and the production and detection of reactive oxygen species. Redox Biol. 4, 381-398.

19. Sturza A., Duicu O.M., Vaduva A., Dănilă M.D., Noveanu L., Varró A., Muntean D.M. 2015. Monoamine oxidases are novel sources of cardiovascular oxidative stress in experimental diabetes. Can. J. Physiol. Pharmacol. 93 (7), 555-561.

20. Goncharov N., Avdonin P., Nadeev A., Zharkikh I., Jenkins R. 2015. Reactive oxygen species in pathogenesis of atherosclerosis. Curr. Pharm. Des. 21 (9), 11341146.

21. Jaffe E.A., Nachman R.L., Becker C.G., Minick C.R. 1973. Culture of human endothelial cells derived from umbilical veins. Identification by morphologic and immunologic criteria. J. Clin. Invest. 52 (11), 2745-2756.

22. Jaffe E.A., Hoyer L.W., Nachman R.L. 1974. Synthesis of von Willebrand factor by cultured human endothelial cells. Proc. Nat. Acad. Sci. USA. 71 (5), 1906-1909.

23. Goncharov N.V., Nadeev A.D., Jenkins R.O., Avdonin P.V. 2017. Markers and biomarkers of endothelium: When something is rotten in the state. Oxid. Med. Cell. Longev. 2017, Article ID 9759735. https://doi.org/10.1155/2017/9759735

24. Petrovic N., Schacke W., Gahagan J.R. O'Conor C.A., Winnicka B., Conway R.E., Mina-Osorio P., Shapiro L.H. 2007. CD13/APN regulates endothelial invasion and filopodia formation. Blood. 110 (1), 142-150.

25. Yamamoto H., Ehling M., Kato K. Kanai K., van Lessen M., Frye M., Zeuschner D., Nakayama M., Vestweber D., Adams R.H. 2015. Integrin $\beta 1$ controls VEcadherin localization and blood vessel stability. Nat. Commun. 6, 6429. 
26. Zhang Y., Li H., Wei R. Ma J., Zhao Y., Lian Z., Liu Z. 2015. Endothelial cells regulate cardiac myocyte reorganisation through $\beta 1$-integrin signaling. Cell. Physiol. Biochem. 35 (5), 1808-1820.

27. Riccieri V., Stefanantoni K., Vasile M. Macrì V., Sciarra I., Iannace N., Alessandri C., Valesini G. 2011. Abnormal plasma levels of different angiogenic molecules are associated with different clinical manifestations in patients with systemic sclerosis. Clin. Exp. Rheumatol. 29 (2, Suppl. 65), S46-S52.

28. Sidney L.E., Branch M.J., Dunphy S.E., Dua H.S., Hopkinson A. 2014. Concise review: Evidence for CD34 as a common marker for diverse progenitors. Stem Cells. 32 (6), 1380-1389.

29. Park L., Wang G., Moore J., Girouard H., Zhou P., Anrather J., Iadecola C. 2014. The key role of transient receptor potential melastatin- 2 channels in amyloid- $\beta$ induced neurovascular dysfunction. Nat. Commun. 5, 5318.

30. Takahashi-Sato K., Murakawa M., Kimura J., Ito M.A., Matsuoka I. 2013. Loss of ectonucleotidases from the coronary vascular bed after ischemia-reperfusion in isolated rat heart. BMC Cardiovasc. Disord. 3 (1), 53.

31. Helenius M.H., Vattulainen S., Orcholski M., Aho J., Komulainen A., Taimen P., Wang L., de Jesus Perez V.A., Koskenvuo J.W., Alastalo T.P. 2015. Suppression of endothelial CD39/ENTPD1 is associated with pulmonary vascular remodeling in pulmonary arterial hypertension. Am. J. Physiol. Lung Cell Mol. Physiol. 308 (10), L1046-L1057.

32. Beldi G., Wu Y., Sun X., Imai M., Enjyoji K., Csizmadia E., Candinas D., Erb L., Robson S.C. 2008. Regulated catalysis of extracellular nucleotides by vascular CD39/ENTPD1 is required for liver regeneration. Gastroenterology. 135 (5), 1751-1760.

33. Sakimoto S., Marchetti V., Aguilar E., Lee K., Usui Y., Murinello S., Bucher F., Trombley J.K., Fallon R., Wagey R., Peters C., Scheppke E.L., Westenskow P.D., Friedlander M. 2017. CD44 expression in endothelial colony-forming cells regulates neurovascular trophic effect. JCI Insight. 2 (2), article e89906.

34. Mund J.A., Estes M.L., Yoder M.C., Ingram D.A., Case J. 2012. Flow cytometric identification and functional characterization of immature and mature circulating endothelial cells. Arterioscler. Thromb. Vasc. Biol. 32 (4), 1045-1053.

35. Martinelli R., Newton G., Carman C.V., Greenwood J., Luscinskas F.W. 2013. Novel role of CD47 in rat microvascular endothelium: Signaling and regulation of T-cell transendothelial migration. Arterioscler. Thromb. Vasc. Biol. 33 (11), 2566-2576.

36. Page A.V., Liles W.C. 2013. Biomarkers of endothelial activation/dysfunction in infectious diseases. Virulence. 4 (6), 507-516.

37. Cho J., Kennedy D.R., Lin L., Huang M., MerrillSkoloff G., Furie B.C., Furie B. 2012. Protein disulfide isomerase capture during thrombus formation in vivo depends on the presence of $\beta 3$ integrins. Blood. 120 (3), 647-655.

38. Satoh S., Suzuki A., Asari Y., Sato M., Kojima N., Sato T., Tsuchiya N., Sato K., Senoo H., Kato T. 2002. Glomerular endothelium exhibits enhanced expression of costimulatory adhesion molecules, CD80 and CD86, by warm ischemia/reperfusion injury in rats. Lab. Invest. 82 (9), 1209-1217.

39. Goldie L.C., Lucitti J.L., Dickinson M.E., Hirschi K.K. 2008. Cell signaling directing the formation and function of hemogenic endothelium during murine embryogenesis. Blood. 112 (8), 3194-3204.

40. Huizer K., Mustafa D.A.M., Spelt J.C., Kros J.M., Sacchetti A. 2017. Improving the characterization of endothelial progenitor cell subsets by an optimized FACS protocol. PLoS One. 12 (9), e0184895.

https://doi.org/10.1371/journal.pone.0184895

41. Rossi E., Poirault-Chassac S., Bieche I., Chocron R., Schnitzler A., Lokajczyk A., Bourdoncle P., Dizier B., Bacha N.C., Gendron N., Blandinieres A., Guerin C.L., Gaussem P., Smadja D.M. 2019. Human endothelial colony forming cells express intracellular CD133 that modulates their vasculogenic properties. Stem Cell Rev. 15, 590-600. https://doi.org/10.1007/s12015-019-09881-8

42. Golab-Janowska M., Paczkowska E., Machalinski B., Kotlega D., Meller A., Nowacki P., Krzysztof S., Pawel W. 2019. Elevated inflammatory parameter levels negatively correlate with populations of circulating stem cells (CD133+), early endothelial progenitor cells. Curr. Neurovasc. Res. 16, 19. https://doi.org/10.2174/1567202616666190129164906

43. Vestweber D. 2008. VE-cadherin: The major endothelial adhesion molecule controlling cellular junctions and blood vessel formation. Arterioscler. Thromb. Vasc. Biol. 28 (2), 223-232.

44. Jin H. J., Kwon J.H., Kim M., Bae Y.K., Choi S.J., Oh W., Yang Y.S., Jeon H.B. 2016. Downregulation of melanoma cell adhesion molecule (MCAM/CD146) accelerates cellular senescence in human umbilical cord blood-derived mesenchymal stem cells. Stem Cells Transl. Med. 5 (4), 427-439.

45. Zhou Y., Huang H., Yuan L.J., Xiong Y., Huang X., Lin J.X., Zheng M. 2015. CD146 as an adverse prognostic factor in uterine sarcoma. Eur. J. Med. Res. $20(1), 67$.

46. Holmes K., Roberts O.L., Thomas A.M., Cross M.J. 2007. Vascular endothelial growth factor receptor-2: Structure, function, intracellular signalling and therapeutic inhibition. Cell. Signal. 19 (10), 2003-2012.

47. Cui D., Arima M., Takubo K., Kimura T., Horiuchi K., Minagawa T., Matsuda S., Ikeda E. 2015. ADAM12 and ADAM17 are essential molecules for hypoxia-induced impairment of neural vascular barrier function. Sci. Rep. 5 (1), article 12796.

48. Wei J., Liu C.J., Li Z. 2014. ADAMTS-18: A metalloproteinase with multiple functions. Front. Biosci. 19 (8), 1456-1467.

49. Borst O., Abed M., Alesutan I., Towhid S.T., Qadri S.M., Föller M., Gawaz M., Lang F. 2012. Dynamic adhesion of eryptotic erythrocytes to endothelial cells via CXCL16/SR-PSOX. Am. J. Physiol. Cell Physiol. 302 (4), C644-C651.

50. Frigo G., Tramentozzi E., Orso G., Ceolotto G., Pagetta A., Stagni C., Menin C., Rosato A., Finotti P. 2016. Human IgGs induce synthesis and secretion of 
IgGs and neonatal Fc receptor in human umbilical vein endothelial cells. Immunobiology. 221 (12), 1329-1342.

51. Garmy-Susini B., Jin H., Zhu Y., Sung R.J., Hwang R., Varner J. 2005. Integrin $\alpha_{4} \beta_{1}-$ VCAM-1-mediated adhesion between endothelial and mural cells is required for blood vessel maturation. J. Clin. Invest. 115 (6), 1542-1551.

52. Hale A.T., Tian H., Anih E., Recio F.O. 3rd, Shatat M.A., Johnson T., Liao X., Ramirez-Bergeron D.L., Proweller A., Ishikawa M., Hamik A. 2014. Endothelial Krüppel-like factor 4 regulates angiogenesis and the Notch signaling pathway. J. Biol. Chem. 289 (17), 12016-12028.

53. Yoshida T., Yamashita M., Iwai M., Hayashi M. 2016. Endothelial Krüppel-like factor 4 mediates the protective effect of statins against ischemic AKI. J. Am. Soc. Nephrol. 27 (5), 1379-1388.

54. Briot A., Bouloumie A., Iruela-Arispe M.L. 2016. Notch, lipids, and endothelial cells. Curr. Opin. Lipidol. 27 (5), 513-520.

55. Bennani-Baiti B., Toegel S., Viernstein H., Urban E., Noe C.R., Bennani-Baiti I.M. 2015. Inflammation modulates RLIP76/RALBP1 electrophile-glutathione conjugate transporter and housekeeping genes in human blood-brain barrier endothelial cells. PLoS One. 10 (9), article e0139101.

56. Milam K.E., Parikh S.M. 2015. The angiopoietin-Tie2 signaling axis in the vascular leakage of systemic inflammation. Tissue Barriers. 3 (1-2), article e957508.

57. Kellett K.A.B., Hooper N.M. 2015. The role of tissue non-specific alkaline phosphatase (TNAP) in neurodegenerative diseases: Alzheimer's disease in the focus. Subcell. Biochem. 76, 363-374.

58. Starke R.D., Ferraro F., Paschalaki K.E., Dryden N.H., McKinnon T.A., Sutton R.E., Payne E.M., Haskard D.O., Hughes A.D., Cutler D.F., Laffan M.A., Randi A.M. 2011. Endothelial von Willebrand factor regulates angiogenesis. Blood. 117 (3), 1071-1080.

59. Valentijn K.M., Eikenboom J. 2013. Weibel-Palade bodies: A window to von Willebrand disease. J. Thromb. Haemost. 11 (4), 581-592.

60. Lenting P.J., Christophe O.D., Denis C.V. 2015. Von Willebrand factor biosynthesis, secretion, and clearance: Connecting the far ends. Blood. 125 (13), 20192028.

61. Turner N.A., Nolasco L., Ruggeri Z.M., Moake J.L. 2009. Endothelial cell ADAMTS-13 and VWF: Production, release, and VWF string cleavage. Blood. 114 (24), 5102-5111.

62. Shim K., Anderson P.J., Tuley E.A., Wiswall E., Evan Sadler J. 2008. Platelet-VWF complexes are preferred substrates of ADAMTS13 under fluid shear stress. Blood. 111 (2), 651-657.

63. Randi A.M., Laffan M.A. 2017. Von Willebrand factor and angiogenesis: Basic and applied issues. J. Thromb. Haemost. 15 (1), 13-20.

64. Bönner G. 1990. Kinin-related effects of angiotensinconverting enzyme inhibition. Clin. Physiol. Biochem. 8 (Suppl. 1), 6-15.

65. Hemming M.L., Selkoe D.J. 2005. Amyloid $\beta$-protein is degraded by cellular angiotensin-converting enzyme
(ACE) and elevated by an ACE inhibitor. J. Biol. Chem. 280 (45), 37644-37650.

66. Li W., Moore M.J., Vasilieva N., Sui J., Wong S.K., Berne M.A., Somasundaran M., Sullivan J.L., Luzuriaga K., Greenough T.C., Choe H., Farzan M. 2003. Angiotensin-converting enzyme 2 is a functional receptor for the SARS coronavirus. Nature. 426 (6965), 450-454.

67. Gaddam R., Chambers S., Bhatia M. 2014. ACE and ACE2 in inflammation: A tale of two enzymes. Inflamm. Allergy Drug Targets. 13 (4), 224-234.

68. Iwai M., Horiuchi M. 2009. Devil and angel in the renin-angiotensin system: ACE-angiotensin II-AT ${ }_{1}$ receptor axis vs. ACE2-angiotensin-(1-7)-mas receptor axis. Hypertens. Res. 32 (7), 533-536.

69. Chappell M.C. 2007. Emerging evidence for a functional angiotensin-converting enzyme 2-angiotensin(1-7)-MAS receptor axis: More than regulation of blood pressure? Hypertension. 50 (4), 596-599.

70. Wang H.J., Chen S.F., Lo W.Y. 2016. Identification of Cofilin-1 induces G0/G1 arrest and autophagy in angiotensin-(1-7)-treated human aortic endothelial cells from iTRAQ quantitative proteomics. Sci. Rep. 6, article 35372.

71. Roskoski R. Jr. 2017. Vascular endothelial growth factor (VEGF) and VEGF receptor inhibitors in the treatment of renal cell carcinomas. Pharmacol. Res. 120, 116-132.

72. Nesmith J.E., Chappell J.C., Cluceru J.G., Bautch V.L. 2017. Blood vessel anastomosis is spatially regulated by Flt1 during angiogenesis. Development. 144 (5), 889896.

73. Zhang M., Jiang L. 2016. Oxidized low-density lipoprotein decreases VEGFR2 expression in HUVECs and impairs angiogenesis. Exp. Ther. Med. 12 (6), 3742-3748.

74. Eklund L., Kangas J., Saharinen P. 2017. Angiopoietin-tie signalling in the cardiovascular and lymphatic systems. Clin. Sci. (Lond.). 131 (1), 87-103.

75. Armulik A., Genove G., Betsholtz C. 2011. Pericytes: Developmental, physiological, and pathological perspectives, problems, and promises. Dev. Cell. 21 (2), 193-215.

76. Park Y.S., Kim G., Jin Y.M., Lee J.Y., Shin J.W., Jo I. 2016. Expression of angiopoietin-1 in hypoxic pericytes: Regulation by hypoxia-inducible factor- $2 \alpha$ and participation in endothelial cell migration and tube formation. Biochem. Biophys. Res. Commun. 469 (2), 263269.

77. Gavard J., Gutkind J.S. 2006. VEGF controls endothelial-cell permeability by promoting the $\beta$-arrestin-dependent endocytosis of VE-cadherin. Nat. Cell Biol. 8 (11), 1223-1234.

78. Shen J., Frye M., Lee B.L., Reinardy J.L., McClung J.M., Ding K., Kojima M., Xia H., Seidel C., Lima e Silva R., Dong A., Hackett S.F., Wang J., Howard B.W., Vestweber D., Kontos C.D., Peters K.G., Campochiaro P.A. 2014. Targeting VE-PTP activates TIE2 and stabilizes the ocular vasculature. J. Clin. Invest. 124 (10), 45644576.

79. Kalinowska A., Losy J. 2006. PECAM-1, a key player in neuroinflammation. Eur. J. Neurol. 13 (12), 12841290. 
80. Li Q., Syrovets T., Simmet T., Ding J., Xu J., Chen W., Zhu D., Gao P. 2013. Plasmin induces intercellular adhesion molecule 1 expression in human endothelial cells via nuclear factor- $\kappa \mathrm{B} /$ mitogen-activated protein kinases-dependent pathways. Exp. Biol. Med. (Maywood). 238 (2), 176-186.

81. Wong D., Dorovini-Zis K. 1992. Upregulation of intercellular adhesion molecule-1 (ICAM-1) expression in primary cultures of human brain microvessel endothelial cells by cytokines and lipopolysaccharide. J. Neuroimmunol. 39 (1-2), 11-21.

82. Yang L., Froio R.M., Sciuto T.E., Dvorak A.M., Alon R., Luscinskas F.W. 2005. ICAM-1 regulates neutrophil adhesion and transcellular migration of TNF- $\alpha$-activated vascular endothelium under flow. Blood. 106 (2), 584-592.

83. Lawson C., Wolf S. 2009. ICAM-1 signaling in endothelial cells. Pharmacol. Rep. 61 (1), 22-32.

84. Muro S., Gajewski C., Koval M., Muzykantov V.R. 2005. ICAM-1 recycling in endothelial cells: A novel pathway for sustained intracellular delivery and prolonged effects of drugs. Blood. 105 (2), 650-658.

85. Muro S., Mateescu M., Gajewski C., Robinson M., Muzykantov V.R., Koval M. 2006. Control of intracellular trafficking of ICAM-1-targeted nanocarriers by endothelial $\mathrm{Na}^{+} / \mathrm{H}^{+}$exchanger proteins. Am. J. Physiol. Lung Cell Mol. Physiol. 290 (5), L809-L817.

86. Malli R., Frieden M., Trenker M., Graier W.F. 2005. The role of mitochondria for $\mathrm{Ca}^{2+}$ refilling of the endoplasmic reticulum. J. Biol. Chem. 280 (13), 1211412122.

87. Malli R., Frieden M., Osibow K., Zoratti C., Mayer M., Demaurex N., Graier W.F. 2003. Sustained $\mathrm{Ca}^{2+}$ transfer across mitochondria is essential for mitochondrial $\mathrm{Ca}^{2+}$ buffering, store-operated $\mathrm{Ca}^{2+}$ entry, and $\mathrm{Ca}^{2+}$ store refilling. J. Biol. Chem. 278 (45), 4476944779.

88. Hu Q., Ziegelstein R.C. 2000. Hypoxia/reoxygenation stimulates intracellular calcium oscillations in human aortic endothelial cells. Circulation. 102 (20), 25412547.

89. Camello-Almaraz C., Gomez-Pinilla P.J., Pozo M.J., Camello P.J. 2006. Mitochondrial reactive oxygen species and $\mathrm{Ca}^{2+}$ signaling. Am. J. Physiol. Cell Physiol. 291 (5), C1082-C1088.

90. Ichimura H., Parthasarathi K., Quadri S., Issekutz A.C., Bhattacharya J. 2003. Mechano-oxidative coupling by mitochondria induces proinflammatory responses in lung venular capillaries. J. Clin. Invest. 111 (5), 691-699.

91. Pires P.W., Earley S. 2017. Redox regulation of transient receptor potential channels in the endothelium. Microcirculation. 24 (3), article e12329.

92. Montell C., Birnbaumer L., Flockerzi V., Bindels R.J., Bruford E.A., Caterina M.J., Clapham D.E., Harteneck C., Heller S., Julius D., Kojima I., Mori Y., Penner R., Prawitt D., Scharenberg A.M., Schultz G., Shimizu N., Zhu M.X. 2002. A unified nomenclature for the superfamily of TRP cation channels. Mol. Cell. 9 (2), 229-231.

93. Sumoza-Toledo A., Penner R. 2011. TRPM2: A multifunctional ion channel for calcium signaling. J. Physiol. 589 (7), 1515-1525.
94. Hara Y., Wakamori M., Ishii M., Maeno E., Nishida M., Yoshida T., Yamada H., Shimizu S., Mori E., Kudoh J., Shimizu N., Kurose H., Okada Y., Imoto K., Mori Y. 2002. LTRPC2 $\mathrm{Ca}^{2+}$-permeable channel activated by changes in redox status confers susceptibility to cell death. Mol. Cell. 9 (1), 163-173.

95. Koizumi K., Wang G., Park L. 2016. Endothelial dysfunction and amyloid- $\beta$-induced neurovascular alterations. Cell. Mol. Neurobiol. 36 (2), 155-165.

96. Suresh K., Servinsky L., Reyes J., Baksh S., Undem C., Caterina M., Pearse D.B., Shimoda L.A. 2015. Hydrogen peroxide-induced calcium influx in lung microvascular endothelial cells involves TRPV4. Am. J. Physiol. Lung Cell Mol. Physiol. 309 (12), L1467-L1477.

97. Avdonin P.V., Nadeev A.D., Tsitrin E.B., Tsitrina A.A., Avdonin P.P., Mironova G.Y., Zharkikh I.L., Goncharov N.V. 2017. Involvement of two-pore channels in the elevation of cytoplasmic $\mathrm{Ca}^{2+}$ level in human umbilical vein endothelial cells induced by hydrogen peroxide. Dokl. Biochem. Biophys. 474 (4), 1-4.

98. Lee J., Kang I.J., Bünger R., Kang Y.H. 2004. Enhanced survival effect of pyruvate correlates MAPK and $\mathrm{NF}-\kappa \mathrm{B}$ activation in hydrogen peroxide-treated human endothelial cells. J. Appl. Physiol. 96 (2), 793801.

99. Xie C.L., Hu L.Q., Pan Y.B., Qian Y.N. 2015. Propofol attenuation of hydrogen peroxide-induced injury in human umbilical vein endothelial cells involves aldose reductase. Pharmazie. 70 (2), 103-109.

100. Erusalimsky J.D. 2009. Vascular endothelial senescence: From mechanisms to pathophysiology. J. Appl. Physiol. 106 (1), 326-332.

101. Kida Y., Goligorsky M.S. 2016. Sirtuins, cell senescence, and vascular aging. Can. J. Cardiol. 32 (5), 634641.

102. Savoia C., Battistoni A., Calvez V., Cesario V., Montefusco G., Filippini A. 2017. Microvascular alterations in hypertension and vascular aging. Curr. Hypertens. Rev. 13 (1), 16-23.

103. Sepulveda C., Palomo I., Fuentes E. 2017. Mechanisms of endothelial dysfunction during aging: Predisposition to thrombosis. Mech. Ageing Dev. 164, 91-99.

104. Dijke P., Egorova A.D., Goumans M.J., Poelmann R.E., Hierck B.P. 2012. TGF- $\beta$ signaling in endothelial-tomesenchymal transition: The role of shear stress and primary cilia. Sci. Signal. 5 (212), pt2. https://doi.org/10.1126/scisignal.2002722

105. Sanchez-Duffhues G., Orlova V., Ten Dijke P. 2016. In brief: Endothelial-to-mesenchymal transition. J. Path. 238 (3), 378-380.

106. Rieder F., Kessler S.P., West G.A., Bhilocha S., de la Motte C., Sadler T.M., Gopalan B., Stylianou E., Fiocchi C. 2011. Inflammation-induced endothelialto-mesenchymal transition: A novel mechanism of intestinal fibrosis. Am. J. Pathol. 179 (5), 2660-2673.

107. Welch-Reardon K.M., Wu N., Hughes C.C.W. 2015. A role for partial endothelial-mesenchymal transitions in angiogenesis? Arterioscler. Thromb. Vasc. Biol. 35 (2), 303-308.

108. Piera-Velazquez S., Mendoza F., Jimenez S. 2016. Endothelial to mesenchymal transition (EndoMT) in the pathogenesis of human fibrotic diseases. J. Clin. Med. 
5 (4). pii E45.

https://doi.org/10.3390/jcm5040045

109. Correia A.C.P., Moonen J.R.A.J., Brinker M.G.L., Krenning G. 2016. FGF2 inhibits endothelial-mesenchymal transition through microRNA-20a-mediated repression of canonical TGF- $\beta$ signaling. J. Cell Sci. 129 (3), 569-579.

110. Kumarswamy R., Volkmann I., Jazbutyte V., Dangwal S., Park D.H., Thum T. 2012. Transforming growth factor- $\beta$-induced endothelial-to-mesenchymal transition is partly mediated by microRNA-21. Arterioscler. Thromb. Vasc. Biol. 32 (2), 361-369.

111. Dejana E., Hirschi K.K., Simons M. 2017. The molecular basis of endothelial cell plasticity. Nat. Commun. 8, article 14361 .

112. Medici D., Kalluri R. 2012. Endothelial-mesenchymal transition and its contribution to the emergence of stem cell phenotype. Seminar. Cancer Biol. 22 (5-6), 379-384.

113. Wang J., Feng Y., Wang Y., Xiang D., Zhang X., Yuan F. 2017. Autophagy regulates endothelial-mesenchymal transition by decreasing the phosphorylation level of Smad3. Biochem. Biophys. Res. Commun. 487 (3), 740747.

114. Ubil E., Duan J., Pillai I.C.L., Rosa-Garrido M., Wu Y., Bargiacchi F., Lu Y., Stanbouly S., Huang J., Rojas M., Vondriska T.M., Stefani E., Deb A. 2014. Mesenchymal-endothelial transition contributes to cardiac neovascularization. Nature. 514 (7524), 585-590.

115. Mendoza F.A., Mansoor M., Jimenez S.A. 2016. Treatment of rapidly progressive systemic sclerosis: Current and futures perspectives. Expert Opin. Orphan Drugs. 4 (1), 31-47.
116. Qi Q., Mao Y., Tian Y., Zhu K., Cha X., Wu M., Zhou X. 2017. Geniposide inhibited endothelial-mesenchymal transition via the mTOR signaling pathway in a bleomycin-induced scleroderma mouse model. Am. J. Transl. Res. 9 (3), 1025-1036.

117. Yamashita T., Asano Y., Taniguchi T., Nakamura K., Saigusa R., Miura S., Toyama T., Takahashi T., Ichimura Y., Yoshizaki A., Trojanowska M., Sato S. 2017. Glycyrrhizin ameliorates fibrosis, vasculopathy, and inflammation in animal models of systemic sclerosis. J. Invest. Dermatol. 137 (3), 631-640.

118. Goncharov N.V., Terpilowski M.A., Nadeev A.D., Kudryavtsev I.V., Serebriakova M.K., Zinchenko V.P., Avdonin P.V. 2018. Cytotoxic power of hydrogen peroxide effect on endothelial cells in vitro. Biochem. (Moscow), Suppl. Series A: Membr. Cell Biol. 12 (2), 180-188. https://doi.org/10.1134/S199074781802006X

119. Han Y., Li L., Zhang Y., Ye L., Zhao J., Duan D.D. 2015. Phenomics of vascular disease: The systematic approach to the combination therapy. Curr. Vasc. Pharmacol. 13 (4), 433-440.

120. Schilling C.H., Edwards J.S., Palsson B.O. 1999. Toward metabolic phenomics: Analysis of genomic data using flux balances. Biotechnol. Prog. 15 (3), 288-295.

121. Defago M.D., Elorriaga N., Irazola V.E., Rubinstein A.L. 2014. Influence of food patterns on endothelial biomarkers: A systematic review. J. Clin. Hypertens. 16 (12), 907-913.

122. Alghadir A.H., Gabr S.A., Al-Eisa E.S. 2016. Effects of moderate aerobic exercise on cognitive abilities and redox state biomarkers in older adults. Oxid. Med. Cell. Longev. 2016, article ID 2545168, 8.

Translated by E. Puchkov 